\title{
Long-Run Money Demand in Ghana: In Search of Stability
}

\author{
Michael Asiedu ${ }^{1 *}$, Sabi Couscous Mouhamadou Nazirou², Soazafy Joyce Sabrina² \\ ${ }^{1}$ School of Finance, Zhongnan University of Economics and Law, Wuhan, China \\ ${ }^{2}$ School of Economics, Zhongnan University of Economics and Law, Wuhan, China \\ Email: masiedu256@gmail.com, naziroucouscous@gmail.com, soajoyce23@yahoo.fr
}

How to cite this paper: Asiedu, M., Nazirou, S. C. M., \& Sabrina, S. J. (2020). Long-Run Money Demand in Ghana: In Search of Stability. Journal of Financial Risk Management, 9, 418-433. https://doi.org/10.4236/jfrm.2020.94022

Received: September 13, 2020

Accepted: November 22, 2020

Published: November 25, 2020

Copyright ( 2020 by author(s) and Scientific Research Publishing Inc. This work is licensed under the Creative Commons Attribution International License (CC BY 4.0).

http://creativecommons.org/licenses/by/4.0/

\begin{abstract}
In this study, we employed annual time series data of Ghana from 1982 to 2019 to examine the long-run money demand function and its stability. Through the methods of co-integration, Vector Error Correction Model, Auto-regressive Distributed Lag bounds test, CUSUM test (cumulative sum of the recursive residuals) and CUSUM sq test (cumulative sum squared of the recursive residuals) we established total stability and long-run relationship between money demand function and its determining factors. Accordingly, our key recommendation is for monetary policymakers to improve on their supervision and monitoring role in the financial market and institutions to avert failures within the sector such as what happened beginning 2014 with the proliferation of several Ponzi-schemes. Monitoring and supervision are key to the maintenance of confidence and stability in the monetary system.
\end{abstract}

\section{Keywords}

Money Demand, Stability, Co-Integration, CUSUM and CUSUM Squared Test, Ghana

\section{Introduction}

The subject of examining the total amount of money and its stability in an economy has been of significant interest to many researchers for many decades if not centuries. The essence is to understand how changes in the quantity of money supply by monetary authorities (central bank) are affected or related to changes in both domestic and foreign interest rates, the general price level (inflation), exchange rates and income or output levels in an economy. Much of this interest in the quantity theory of money and stability was inspired by the novel work of Keynes (1936) on the General Theory of Employment, Interest 
and Money. Also revealing was the work of Friedman in 1956 (the quantity theory of money) which prompted much interest in understanding not just the roles of money in all modern economies but also how changes in the quantity of money transmit into the real economy. Monetary policymakers often use changes in money supply to achieve inflation and short term interest rate targets. The study of the money demand function and its determinants is important to measure its stability, volatility and capture the effects of international movement of asset prices; economists have been innovative at designing functions that encapsulate all these fundamentals. These determinants include the real domestic income, inflation, exchange rate to capture the effects of the dynamics in the country's currency against other currencies, foreign interest rate to capture the effects of international financial assets and the domestic interest rate.

The Central Bank of Ghana like most other central banks is tasked with the core mandate of ensuring economic growth and price stability in the medium and long-term. Following the 1957 ordinance that set up the Bank of Ghana; the main objectives included the issuance and redeeming of bank notes and coins, maintaining and appropriating reserves to influence the availability of credit to ensure monetary stability in Ghana and a stable exchange environment. The objective of maintaining monetary stability in Ghana is only plausible with a total examination and understanding of the behaviour the monetary aggregates and its determinants over the years. Even though there have been large and growing number of studies on the stability of the money demand function and its determinants; the empirical work related to Ghana is very limited except for who found a stable money demand function. In this study we test for the stability of money demand function and its determinants (including foreign interest rate) using annual time series data from 1982 to 2019.

\section{Literature Review}

From post-World war II quarterly data analysis, Hoffman et al. (1995) found significant presence of long-run stability in the money demand functions (M1) in five (5) advanced economies (West Germany, Japan, U.S., U.K. and Canada). The presence of long-run stability in these economies was tested based on two unique estimation methods. The study found that a significant driver of stability is the adoption of a unitary long-run income elasticity that is hugely supported by the data in majority of the countries under consideration. Bahmani-oskooee et al. (2002) adopted quarterly data spanning from the first quarter of 1985 to the last quarter of 1994; they found co-integrated equations between money demand and its determinants. They also established stability in the money demand function of Hong Kong from of both the CUSUM test and CUSUM squared test. (Haug \& Lucas, 1996) also examined the long-run nexus among real money demand and its determinants (real income and real interest rate). From their examination; they found evidence of a stable cointegrating relationship between 
real money demand (M1) and its determinants in Canada from the first quarter of 1953 to the last quarter of 1990. Karfakis \& Opoulos (2000) recommended the adoption of narrow money balances (M1) as a medium term monetary policy target in Greece based on the evidence of stability in the long-run money demand function during the sample period of first quarter 1986 to 1995 . These findings was established through a co-integration test of the relationship between real money aggregates and its determinants (real income and interest rate) using quarterly time series data.

An examination the financial development in three (3) emerging economies (Bahrain, The UAE, and Qatar) and the stability of their co-integrating money demand functions; Darrat \& Al-Sowaidi (2009) established that the rapid pace of financial development and financial deepening of these economies did not trigger any significant shifts in their money demand functions. They also found that in terms of monetary policy targeting through co-integration test of stability; M1 is best for UAE whilst M2 works best for Qatar. In the case Bahrain, M1 and M2 proved to have the same magnitude and direction. Based on these findings, they suggested that; monetary authorities should closely monitor the growth of monetary aggregates as target policy guide. Following the bounds testing method developed by Pesaran et al. (2001), Dagher \& Kovanen (2011) tested the long-run money demand function and its stability of for Ghana. Their study provided significant evidence of stability, co-integration between the money demand function and its determinants in Ghana. They concluded based on the empirical evidence; the existence of a complex relationship between money demand and its determinants. However; equilibrium deviations are short lived.

Chen (1997) tested the stability of the long-run money demand function using three (3) different measures of monetary aggregates in China from 1951 to 1991. The study found the presence of a stable long-run money demand functions using $\mathrm{M} 0$ and $\mathrm{M} 2$ for the entire sample period, covering both the pre and post-reform years. The study also revealed that the respective income elasticities for the real money balances (M0 and M2) were about $1.4-1.5$ and 1.8 1.9. He therefore concluded that; keeping the growth rate of M2 below $28 \%$ $29 \%$ will help maintain inflation below $10 \%$. Sarwar et al. (2013) adopted an annual time series data and co-integration technique to investigate the presence of long-run and short run relationship between monetary aggregates (M0, M1 and M2) and its determinants in Pakistan. The test results from the study revealed that, only broad money (M2) supported a stable money demand function. Meanwhile; income and interest rate were found to be positively and negatively related real money demand balances. Foresti \& Napolitano (2013) also examined the presence of a stable long run money demand function of nine (9) OECD countries (G7 plus Australia and Switzerland) based on panel DOLS and between-dimension group-mean panel DOLS techniques introduced by Mark \& Sul (2003) and Pedroni (2001) respectively using quarterly 
data from 1982 to 2008. Using income and wealth interchangeably, they found that wealth has a positive elasticity and plays a significant role in the determination and stability of the money demand function.

To understand the significance the money demand function in Malaysia, Ali \& Abdul-Manap (2009) conducted an empirical enquiry into the stability of money demand functions using both M1 and M2. From the study; cointegrating equations were established between the monetary aggregates (M1 and M2) and their determinants. However; long run stability was only achieved in M1. Evidence was found that the stability function for M2 became unstable after 1997. This finding opposes the findings of Nair et al. (2008) who concluded that the Asian financial crises had no effect on the stability of money demand in Malaysia.

Alvarez \& Lippi (2014) provided evidence from a segmented asset market following a one-time increase in liquidity; which implies a continuous fall in interest rates. The study found that the intertemporal substitution and the long-run interest rate elasticities of money demand influenced the magnitude of the liquidity effect. Dritsaki \& Dritsaki (2020) also examined the factors underlining the money demand function in Italy using annual time series data from 1960-2017. From an ARDL model, co-integration and a vector error correction model (VECM); the long-run and short run coefficients were also estimated. The results from the CUSUM test indicated the presence of a stable long-run and short run when the study adopted M1 for the period under consideration. Benati et al. (2020) confirmed the existence of a long-run stable relationship between M1 to GDP ratio and short-term interest rate from a study investigating the long-run behaviour of the demand of M1 consisting of 38 countries. The estimated elasticity of interest rate was found between 0.3 and 0.6. Suliman \& Dafaalla (2011) found the presence of long-run relationship between real monetary aggregates and its determinants in Sudan from the period 1960 -2010. Their study also confirms the stability of the money demand function for the same period.

\section{Data Description and Source}

The data for this study is obtained from the World Development Indicators (WDI) and macotrends.net. The data consist of annual time series data from 1982 to 2019. All the variables except inflation were expressed in natural logarithms.

Price index: Inflation-CPI (Based 2010=100) as the price level;

M2 is the nominal money level;

GDP is measured as the GDP (constant local currency unit;

The three (3) month Libor rate is short term Foreign interest rate;

The 91 days Treasury bill rate is the short term domestic interest rate;

Exchange rate is measured as the official exchange rate (LCU per US\$, period average). 


\subsection{Methodology}

The study employs both vector error correction model (VECM) and the bounds test of auto-regressive distributed lag model (ARDL), co-integration test for long-run nexus, CUSUM test and CUSUM squared test for the stability of money demand function in Ghana.

\subsection{Model Specification}

It is common in the macroeconomic literature to find a money demand function expressed

$$
M / P=f(Y, O c) ;
$$

where: $M$ represents nominal value of money, $P$ is price level, $Y$ is income, and $O v$ is the vector of opportunity cost of money holding.

However; in this study we express the money demand function specifically as:

$$
\text { RM2 }=f(\text { Exch, Infl, RGDP, Libor, 91days })
$$

where RM2 is real monetary aggregate (M2), Exch is the real official effective exchange rate, Libor is the representation of the foreign interest rate, RGDP is real income.

Equation (1) is transformed into Equation (2)

$$
\begin{aligned}
\ln \mathrm{RM}_{t}= & \beta_{0}+\beta_{1} \ln \text { Exch }_{t}+\beta_{2} \operatorname{Infl}_{t}+\beta_{3} \ln \mathrm{RGDP}_{t} \\
& +\beta_{4} \ln \text { Libor }_{t}+\beta_{5} \ln \text { 91days } t \\
t & \varepsilon_{t}
\end{aligned}
$$

where the Parameters: $\beta_{1}, \beta_{2}, \beta_{3}, \beta_{4}$ and $\beta_{5}$ denote exchange rate elasticity, partial-elasticity in relation to inflation, income elasticity, foreign interest rate elasticity and domestic interest rate elasticity respectively. The income elasticity coefficient is significant for the determination of monetary expansion which is consistent with the long-run price stability level and the interest rate elasticity helps to derive the welfare cost of long term inflation Mark \& Sul (2003).

\subsection{ARDL Model Specification}

The equation for the auto-regressive distributed lag (ARDL) model is specified as below after the test for unit root I (0), I (1), co-integration and bounds test.

$$
\begin{aligned}
\Delta & \left(\ln \mathrm{RM}_{2}\right)_{t} \\
= & \lambda_{0}+\lambda_{1}(\ln \mathrm{RM} 2)_{t-1}+\lambda_{2} \text { Exch }_{t-1}+\lambda_{3} \operatorname{Infl}_{t-1}+\lambda_{4} \ln \mathrm{RGDP}_{t-1} \\
& +\lambda_{5} \text { Libor }_{t-1}+\sum_{j=1}^{l} \mathcal{J} 1 j \Delta(\ln \mathrm{RM} 2)_{t-j}+\sum_{j=0}^{m} \mathcal{J} 2 j \Delta \ln \mathrm{RGDP}_{t-j} \\
& +\sum_{j=0}^{n} \mathcal{J} 3 j \Delta \ln \operatorname{Exch}_{t-j}+\sum_{j=0}^{o} \mathcal{J} 4 j \Delta \ln \operatorname{Infl}_{t-j} \\
& +\sum_{j=0}^{p} \mathcal{J} 5 j \Delta \ln \operatorname{LIOBR}_{t-j}+\sum_{j=0}^{q} \mathcal{J} 5 j \Delta \ln \text { 91days }{ }_{t-j}+\varepsilon_{t}
\end{aligned}
$$

From the evidence of one co-integration (Ghana) the Error Correction Model is specified

$$
\begin{aligned}
& \mathrm{ECT}=\ln (\mathrm{RM} 2)_{t}-\left(\delta_{0}+\delta_{1} \ln \mathrm{Exch}_{t}+\delta_{2} \mathrm{Infl}_{t}+\delta_{3} \ln \mathrm{RGDP}_{t}\right. \\
& \left.+\delta_{4} \text { Libor }_{t}+\delta_{5} \ln \text { 91days }{ }_{t}\right)
\end{aligned}
$$


The descriptive statistic of the variables is reported in Table 1. With a total of 38 observations, the table records significant variations of the variables from their mean values. The minimum and maximum values of the data are reported in columns 5 and 6 respectively.

The test for correlation and statistical significance among the variables is reported in Table 2. The results raises some concern for the presence of multicollinearity since some of the correlation coefficients are significantly high; especially between real money demand (lnrm2) and the following dependent variables, income (lnrgdp), exchange rate (Exch) and LIBOR.

The unit root test of the variables is presented in Table 3. Since this study employs both the VECM and ARDL bounds test; the appropriateness of

Table 1. Descriptive statistics.

\begin{tabular}{cccccc}
\hline Variable & Obs & Mean & Std.Dev. & Min & Max \\
\hline Inrm2 & 38 & 17.201 & 3.711 & 9.735 & 23.05 \\
Lnrgdp & 38 & 18.705 & 3.459 & 11.915 & 24.362 \\
Infl & 38 & 27.998 & 21.213 & 9.189 & 123.061 \\
Exch & 38 & 1.1 & 1.462 & 0 & 5.217 \\
LIBOR & 38 & 4.33 & 3.106 & 0.23 & 9.73 \\
$\ln 91$ days & 38 & 3.008 & 0.429 & 2.251 & 3.756 \\
\hline
\end{tabular}

Table 2. Pairwise correlations.

\begin{tabular}{|c|c|c|c|c|c|c|}
\hline Variables & (1) & (2) & (3) & (4) & (5) & (6) \\
\hline (1) $\operatorname{lnrm} 2$ & 1.000 & (1) $\ln r m 2$ & & & & \\
\hline (2) lnrgdp & $0.999^{*}$ & 1.000 & (2) lnrgdp & & & \\
\hline (3) Infl & $-0.520^{*}$ & $-0.514^{*}$ & 1.000 & (3) Infl & & \\
\hline (4) Exch & $0.819^{*}$ & $0.837^{\star}$ & $-0.351^{\star}$ & 1.000 & (4) Exch & \\
\hline (5) LIBOR & $-0.886^{\star}$ & $-0.879^{\star}$ & $0.426^{\star}$ & $-0.661^{\star}$ & 1.000 & \\
\hline (6) $\ln 91$ days & -0.123 & -0.137 & -0.092 & -0.299 & 0.023 & 1.000 \\
\hline
\end{tabular}

*Shows significance at the 0.05 level.

Table 3. Augmented Dickey-Fuller test for unit root.

\begin{tabular}{ccc}
\hline Variable & First difference $\mathrm{p}$-value for $\mathrm{Z}(\mathrm{t})$ & Second difference $\mathrm{p}$-value for $\mathrm{Z}(\mathrm{t})$ \\
\hline LnRM2 & 0.6520 & $0.0000^{\star * *}$ \\
LnRGDP & 0.8228 & $0.0000^{\star * *}$ \\
Inflation & $0.0065^{* *}$ & $0.0000^{\star * *}$ \\
lnExch & 0.1085 & $0.0145^{\star *}$ \\
LnLibor & 0.5464 & $0.0020^{* * *}$ \\
Ln91days & $0.0006^{* *}$ & $0.0006^{* *}$ \\
\hline
\end{tabular}

${ }^{* *} p<0.01,{ }^{* *} p<0.05$ shows significance level. 
both models is only approved when the series for the study are made up of variables integrated of order zero I (0) and order I (1) but not I (2).

Selection-order criteria

For the appropriateness and construction of the cointegration test, the study conducted the lag order selection test. The results as reported in Table 4 settles on a maximum lag of four (4) since majority of the lag selection-order criteria are all significant at 4 lags. This means that the AIC, HQIC, FPE and LR selection criteria have all settled on the maximum lag of 4 as shown in Table 4 below.

Johansen tests for cointegration

Trend: constant Number of obs $=36$

Sample: 1984-2019 Lags $=2$

From the Johansen tests for co-integration reported in Table 5 with three co-integrating equations.

\section{Results}

Results of the Vector Error Correction Model are present in Table 6 below.

Sample: $1984-2019 \quad$ Number of obs $=36$

$$
\begin{array}{ll}
\text { Log likelihood }=-45.10355 & \text { AIC }=5.450197 \\
\text { Det }(\text { Sigma_ml) }=4.94 \mathrm{e}-07 & \text { SBIC }=7.781489
\end{array}
$$

Table 4. Sample: $1986-2019$ Number of obs $=34$.

\begin{tabular}{ccccccccc}
\hline Lag & LL & LR & df & P & FPE & AIC & HQIC & SBIC \\
\hline 0 & -310.538 & 4.91702 & 18.6199 & 18.7117 & 18.8892 & & & \\
1 & -104.286 & 412.5 & 36 & 0.000 & 0.000228 & 8.60509 & 9.2481 & $10.4906^{*}$ \\
2 & -64.0705 & 80.432 & 36 & 0.000 & 0.000219 & 8.35709 & 9.55125 & 11.8587 \\
3 & -22.2379 & 83.665 & 36 & 0.000 & 0.00029 & 8.01399 & 9.75931 & 13.1318 \\
4 & 51.1919 & $146.86^{*}$ & 36 & 0.000 & $0.000157^{*}$ & $5.81224^{*}$ & $8.10871^{*}$ & 12.5462 \\
\hline
\end{tabular}

*Shows significance at the 0.05 level.

Table 5. Johansen tests for co-integration.

\begin{tabular}{cccccc}
\hline Maximum Rank & Parms & LL & Eigen value & $\begin{array}{c}\text { Trace } \\
\text { statistic }\end{array}$ & $\begin{array}{c}\text { 5\% Critical } \\
\text { Value }\end{array}$ \\
\hline 0 & 42 & -66.879556 &. & 131.3764 & 94.15 \\
1 & 53 & -45.103549 & 0.70174 & 87.8244 & 68.52 \\
2 & 62 & -28.057982 & 0.61209 & 53.7332 & 47.21 \\
4 & 69 & -14.08747 & 0.53982 & $25.7922^{*}$ & 29.68 \\
5 & 74 & -7.1972758 & 0.31804 & 12.0118 & 15.41 \\
6 & 77 & -2.5100713 & 0.22926 & 2.6374 & 3.76 \\
& 78 & -1.1913661 & 0.07064 & & \\
\hline
\end{tabular}


The differenced equations of the vector error-correction model (VECM) are presented in Table 6 . All the coefficients are statistically significant at $1 \%$ except $\ln 91$ days which is not statistically significant. The coefficient of determination (R-sq) is $69 \%, 72 \%, 73 \%, 83 \% 70 \%$ and $12 \%$ for $\operatorname{lnM} 2$, lnRGDP, lnfl, lnExch, $\operatorname{lnLibor}$ and $\ln 91$ days respectively.

The short-run coefficients of the vector error correction model are reported below in Table 7.

Table 6. Vector error-correction model - differenced equations.

\begin{tabular}{cccccc}
\hline Equation & Parms & RMSE & R-sq & chi $^{2}$ & P $>$ chi $^{2}$ \\
D_lnrm2 & 8 & 0.461196 & 0.6908 & 62.54762 & 0.0000 \\
D_lnrgdp & 8 & 0.39062 & 0.7226 & 72.95491 & 0.0000 \\
D_Infl & 8 & 14.288 & 0.7276 & 74.77142 & 0.0000 \\
D_lnExch & 8 & 0.163028 & 0.8328 & 139.4997 & 0.0000 \\
D_lnLibor & 8 & 0.276881 & 0.7034 & 66.40947 & 0.0000 \\
D_ln91days & 8 & 0.317967 & 0.1214 & 3.868016 & 0.8688 \\
\hline
\end{tabular}

Table 7. Vector error-correction model-Short run coefficients.

\begin{tabular}{|c|c|c|c|c|c|}
\hline Coef. & St.Err & $t$-value & p-value & Sig. & \\
\hline L._ce1 & -0.359 & 0.143 & -2.50 & 0.012 & $* *$ \\
\hline LD.lnrm2 & -1.817 & 0.881 & -2.06 & 0.039 & $* *$ \\
\hline LD.lnrgdp & 1.778 & 0.978 & 1.82 & 0.069 & * \\
\hline LD.Infl & -0.002 & 0.007 & -0.32 & 0.746 & \\
\hline LD.lnExch & 0.551 & 0.277 & 1.99 & 0.047 & $* *$ \\
\hline LD.lnLibor & -0.524 & 0.192 & -2.73 & 0.006 & $* * *$ \\
\hline LD. $\ln 91$ days & -0.549 & 0.277 & -1.98 & 0.048 & $* *$ \\
\hline _cons & 0.482 & 0.182 & 2.64 & 0.008 & $* * *$ \\
\hline L._ce1 & -0.287 & 0.122 & -2.36 & 0.018 & $* *$ \\
\hline LD. $\ln r m 2$ & -1.820 & 0.746 & -2.44 & 0.015 & $* *$ \\
\hline LD.lnrgdp & 1.845 & 0.828 & 2.23 & 0.026 & $* *$ \\
\hline LD.Infl & 0.000 & 0.006 & -0.07 & 0.948 & \\
\hline LD.lnExch & 0.467 & 0.235 & 1.99 & 0.047 & $* *$ \\
\hline LD.InLibor & -0.400 & 0.163 & -2.46 & 0.014 & $* *$ \\
\hline LD. $\ln 91$ days & -0.472 & 0.235 & -2.01 & 0.044 & $* *$ \\
\hline _cons & 0.417 & 0.155 & 2.70 & 0.007 & $* * *$ \\
\hline L._ce1 & 12.697 & 4.445 & 2.86 & 0.004 & $* * *$ \\
\hline LD. $\ln r m 2$ & 64.611 & 27.304 & 2.37 & 0.018 & $* *$ \\
\hline LD.lnrgdp & -82.535 & 30.302 & -2.72 & 0.006 & $* * *$ \\
\hline LD.Infl & -0.425 & 0.217 & -1.96 & 0.050 & $* *$ \\
\hline
\end{tabular}




\section{Continued}

\begin{tabular}{|c|c|c|c|c|c|}
\hline LD. $\ln E x c h$ & -24.179 & 8.594 & -2.81 & 0.005 & $* * *$ \\
\hline LD.lnLibor & 17.308 & 5.954 & 2.91 & 0.004 & $* * *$ \\
\hline LD.ln91days & 14.292 & 8.585 & 1.67 & 0.096 & * \\
\hline _cons & 0.035 & 5.653 & 0.01 & 0.995 & \\
\hline L._ce1 & 0.009 & 0.051 & 0.18 & 0.859 & \\
\hline LD. $\ln r m 2$ & -0.104 & 0.312 & -0.33 & 0.739 & \\
\hline LD.lnrgdp & 0.357 & 0.346 & 1.03 & 0.302 & \\
\hline LD.Infl & 0.008 & 0.002 & 3.23 & 0.001 & $* * *$ \\
\hline LD.lnExch & 0.486 & 0.098 & 4.96 & 0.000 & $* * *$ \\
\hline LD.lnLibor & -0.015 & 0.068 & -0.22 & 0.825 & \\
\hline LD.ln91days & 0.198 & 0.098 & 2.03 & 0.043 & ** \\
\hline _cons & 0.025 & 0.065 & 0.39 & 0.693 & \\
\hline L._ce1 & 0.380 & 0.086 & 4.41 & 0.000 & $* * *$ \\
\hline LD.lnrm2 & -0.994 & 0.529 & -1.88 & 0.060 & * \\
\hline LD.lnrgdp & 1.374 & 0.587 & 2.34 & 0.019 & ** \\
\hline LD.Infl & 0.008 & 0.004 & 1.93 & 0.054 & * \\
\hline LD. $\ln E x c h$ & 0.152 & 0.167 & 0.91 & 0.361 & \\
\hline LD.lnLibor & 0.772 & 0.115 & 6.70 & 0.000 & $* * *$ \\
\hline LD.ln91days & -0.488 & 0.166 & -2.94 & 0.003 & $* * *$ \\
\hline _cons & -0.407 & 0.110 & -3.72 & 0.000 & $* * *$ \\
\hline L._ce1 & -0.030 & 0.099 & -0.30 & 0.762 & \\
\hline LD. $\ln r m 2$ & -0.736 & 0.608 & -1.21 & 0.226 & \\
\hline LD.lnrgdp & 0.809 & 0.674 & 1.20 & 0.230 & \\
\hline LD.Infl & -0.003 & 0.005 & -0.69 & 0.493 & \\
\hline LD.lnExch & -0.076 & 0.191 & -0.40 & 0.690 & \\
\hline LD.lnLibor & 0.051 & 0.132 & 0.39 & 0.699 & \\
\hline LD.ln91days & 0.075 & 0.191 & 0.40 & 0.693 & \\
\hline _cons & 0.025 & 0.126 & 0.20 & 0.844 & \\
\hline Mean dependent var & \multicolumn{2}{|c|}{3.041} & SD dependent var & \multicolumn{2}{|r|}{0.414} \\
\hline Number of obs & \multicolumn{2}{|c|}{36.000} & \multicolumn{2}{|l|}{ Akaike crit. (AIC) } & . \\
\hline
\end{tabular}

${ }^{* * *} p<0.01,{ }^{* *} p<0.05,{ }^{*} p<0.1$.

Table 7 above reports short run elasticity coefficients of the money demand function from the vector error correction model and their respective speed of adjustment coefficients. Majority of the short run coefficients are statistically significant and meet the expected relationship. For example, the elasticity coefficient of income (real GDP) is positive and statistically significant except in the third equation (with Inflation as the dependent variable). The income elasticity is positive $1.778 \%$ at $10 \%$ significance level. This significantly means that, all 
things being equal; a unit increase in income (real GDP) will lead to a corresponding 1.778 increase in real money demand. We also find that income elasticity drops to -82.535 with inflation as the key dependent variable. The income elasticity coefficient is also 1.845 at $5 \%$ significance level with the first difference of real GDP as dependent variable. The statistical significance of all the variables however disappears with natural logarithm of 91 days as the dependent variable.

Cointegrating equations and the long-run coefficients

Table 8 presents the Johansen normalization restriction imposed, also known as the long run coefficients of the model. With lnrm2 positioned as the dependent variables in this model, in the long run lnrgdp, Infl and lnLibor have positive and significant effects on the real demand for money in Ghana. These three explanatory variables are all statistically significant at $1 \%$. However; the natural logarithm of exchange rate and the 91 days treasury bill rates are not statistically significant. This means that in the long run lnrgdp, Infl and lnLibor have symmetrical effect on the natural logarithm of real money demand in Ghana. In addition, we bear in mind that in the long run the signs of the coefficients are reversed. For example, in the long run a unit increase in real income will trigger 1.44 unit increase in the demand for money. This is more than unitary elasticity.

Table 9 present the test of normality and stability of the residual values of the VECM.

The normality test of the residual is reported in Table 9. We find all the test residuals to be normally distributed and stable.

Table 10 is the results of the bounds test with and without (91 days) domestic interest rate.

Table 11 reports the co-integrated demand function (with domestic interest rate-91 days treasury bill rate) in column two (2) and in column three (3)

Table 8. Johansen normalization restriction imposed.

\begin{tabular}{ccccccc}
\hline Beta & Coef. & Std. Err. & $\mathrm{Z}$ & $\mathrm{P}>|\mathbf{z}|$ & [95\% Conf. Interval] \\
\hline cel & & & & & & \\
lnrm2 & 1 & & & & & \\
Lnrgdp & -1.438684 & 0.1715597 & -8.39 & 0.000 & -1.774935 & -1.102433 \\
Infl & -0.030274 & 0.0117391 & -2.58 & 0.010 & -0.0532822 & -0.0072657 \\
InExch & 0.0486902 & 0.2272216 & 0.21 & 0.830 & -0.3966559 & 0.4940362 \\
lnLibor & -0.8055793 & 0.1134232 & -7.10 & 0.000 & -1.027885 & -0.5832739 \\
ln91days & -0.0658378 & 0.2746348 & -0.24 & 0.811 & -0.6041121 & 0.4724366 \\
_cons & 12.3099 & & & & & \\
\hline
\end{tabular}

Table 9. Lagrange-multiplier test.

\begin{tabular}{cccc}
\hline Lag & chi $^{2}$ & df & Prob $>$ chi $^{2}$ \\
\hline 1 & 27.0656 & 36 & 0.85879 \\
2 & 33.1067 & 36 & 0.60694 \\
\hline
\end{tabular}


Table 10. ARDL TEST.

\begin{tabular}{cccc}
\hline Bounds test & F-statistic & & Remark \\
\hline 444444 & 3.483 & Without (91 days) & Not co-integrated \\
11000 & $6.811^{\star * *}$ & With (91 days) & co-integrated \\
\hline
\end{tabular}

Table 11. Regression results.

\begin{tabular}{|c|c|c|}
\hline & $\begin{array}{c}\text { (With } 91 \text { days)) } \\
\quad \ln r \mathrm{~m} 2\end{array}$ & $\begin{array}{c}\text { (Without } 91 \text { days)) } \\
\operatorname{lnrm} 2\end{array}$ \\
\hline \multirow[t]{2}{*}{ L.lnrm2 } & $-0.184^{\star}$ & -0.503 \\
\hline & $(0.104)$ & $(0.286)$ \\
\hline \multirow[t]{2}{*}{ L2. $\operatorname{lnrm} 2$} & & $-1.143^{* *}$ \\
\hline & & $(0.256)$ \\
\hline \multirow[t]{2}{*}{ L3. $\ln r m 2$} & & -0.281 \\
\hline & & $(0.456)$ \\
\hline \multirow[t]{2}{*}{ L4. Inrm2 } & & $0.772^{\star}$ \\
\hline & & $(0.305)$ \\
\hline \multirow[t]{2}{*}{ Lnrgdp } & & $1.145^{\star * *}$ \\
\hline & & $(0.150)$ \\
\hline \multirow[t]{2}{*}{ L.lnrgdp } & & 0.212 \\
\hline & & $(0.352)$ \\
\hline \multirow[t]{2}{*}{ L2.lnrgdp } & & $1.482^{* *}$ \\
\hline & & $(0.343)$ \\
\hline \multirow[t]{2}{*}{ L3.lnrgdp } & & 0.394 \\
\hline & & $(0.665)$ \\
\hline \multirow[t]{2}{*}{ L4.lnrgdp } & & $-1.254^{\star *}$ \\
\hline & & $(0.400)$ \\
\hline \multirow[t]{2}{*}{ Infl } & & 0.003 \\
\hline & & $(0.004)$ \\
\hline \multirow[t]{2}{*}{ L.Infl } & & -0.006 \\
\hline & & $(0.003)$ \\
\hline \multirow[t]{2}{*}{ L2.Infl } & & 0.003 \\
\hline & & $(0.003)$ \\
\hline \multirow[t]{2}{*}{ L3.Infl } & & $-0.010^{\star}$ \\
\hline & & $(0.004)$ \\
\hline \multirow[t]{2}{*}{ L4.Infl } & & $-0.015^{\star *}$ \\
\hline & & $(0.004)$ \\
\hline \multirow[t]{2}{*}{ LnExch } & & -0.333 \\
\hline & & $(0.158)$ \\
\hline L.lnExch & & 0.227 \\
\hline
\end{tabular}




\section{Continued}

\begin{tabular}{|c|c|c|}
\hline & & $(0.376)$ \\
\hline \multirow[t]{2}{*}{ L2.lnExch } & & $1.104^{* *}$ \\
\hline & & $(0.263)$ \\
\hline \multirow[t]{2}{*}{ L3.lnExch } & & $0.630^{*}$ \\
\hline & & $(0.272)$ \\
\hline \multirow[t]{2}{*}{ L4. $\operatorname{lnExch}$} & & $-0.863^{\star *}$ \\
\hline & & $(0.208)$ \\
\hline \multirow[t]{2}{*}{ lnLibor } & & $0.338^{* * *}$ \\
\hline & & $(0.059)$ \\
\hline \multirow[t]{2}{*}{ L.lnLibor } & & $-0.375^{\star *}$ \\
\hline & & $(0.096)$ \\
\hline \multirow[t]{2}{*}{ L2.lnLibor } & & $0.270^{*}$ \\
\hline & & $(0.118)$ \\
\hline \multirow[t]{2}{*}{ L3.lnLibor } & & $-0.230^{*}$ \\
\hline & & $(0.106)$ \\
\hline \multirow[t]{2}{*}{ L4.InLibor } & & $0.502^{* *}$ \\
\hline & & $(0.110)$ \\
\hline \multirow[t]{2}{*}{$\ln 91$ days } & & 0.180 \\
\hline & & $(0.119)$ \\
\hline \multirow[t]{2}{*}{ L.ln91days } & & $0.551^{* *}$ \\
\hline & & $(0.183)$ \\
\hline \multirow[t]{2}{*}{ L2.ln91days } & & $-0.270^{\star *}$ \\
\hline & & $(0.073)$ \\
\hline \multirow[t]{2}{*}{ L3.ln91days } & & $-0.322^{\star *}$ \\
\hline & & $(0.095)$ \\
\hline \multirow[t]{2}{*}{ L4.ln91days } & & -0.135 \\
\hline & & $(0.115)$ \\
\hline \multirow[t]{2}{*}{ _cons } & & 0.907 \\
\hline & & $(2.406)$ \\
\hline \multirow[t]{2}{*}{ LR:lnrgdp } & $0.770^{* * *}$ & \\
\hline & $(0.129)$ & \\
\hline \multirow[t]{2}{*}{ LR:Infl } & -0.025 & \\
\hline & $(0.016)$ & \\
\hline \multirow[t]{2}{*}{ LR:InExch } & $0.350^{* *}$ & \\
\hline & $(0.145)$ & \\
\hline \multirow[t]{2}{*}{ LR:InLibor } & -0.009 & \\
\hline & $(0.093)$ & \\
\hline
\end{tabular}




\section{Continued}

\begin{tabular}{ccc}
\hline SR:D.lnrgdp & $0.864^{* * *}$ & \\
& $(0.112)$ & \\
SR:_cons & $0.733^{*}$ & \\
& $(0.362)$ & 34 \\
Obs. & 37 & 0.989 \\
R-squared & 0.990 & \\
\hline
\end{tabular}

Standard errors are in parenthesis. ${ }^{* *} p<0.01,{ }^{* *} p<0.05,{ }^{*} p<0.1$.

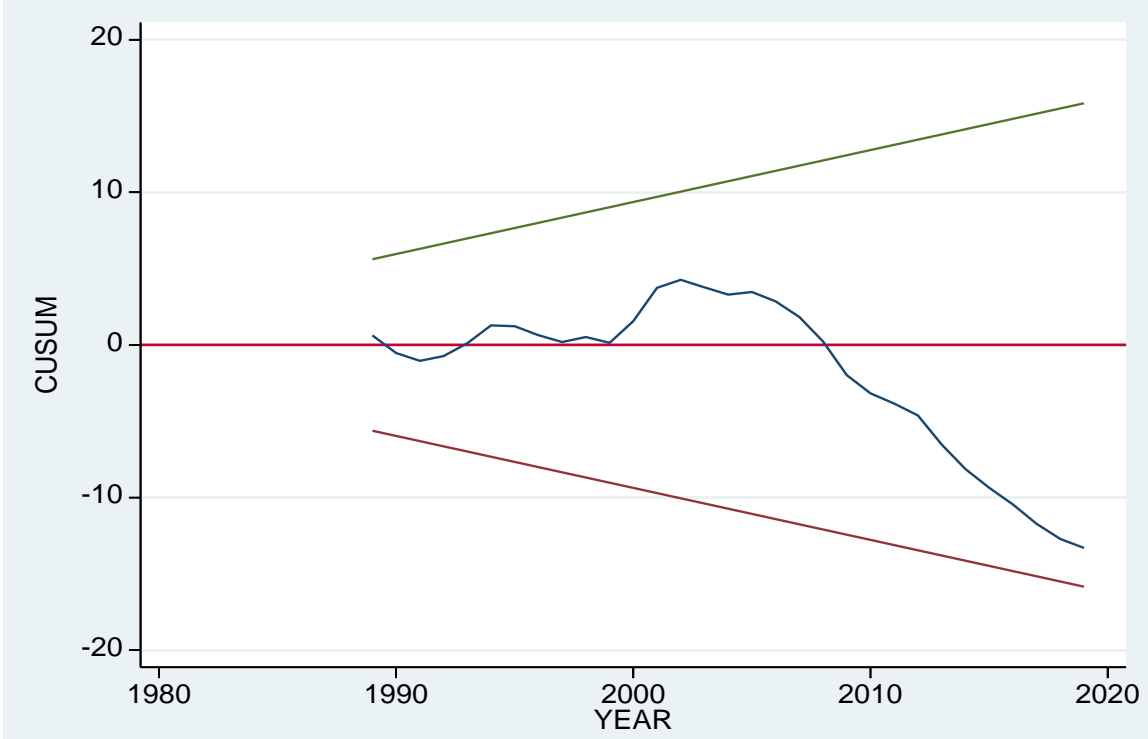

Figure 1. Cusum test for stability of the money demand function.

is the results of the demand function without domestic interest rate (not co-integrated). The long-run elasticity coefficients for income (real GDP) and exchange rate are statistically significant at $1 \%$ and $5 \%$ respectively. The short-run elasticity coefficient of income (real GDP) for the co-integrated money demand function is also statistically significant $1 \%$. From the results of the cointegrated demand function, the elasticity coefficients of real income (lnrgdp) and exchange rate (lnExch) are 0.770 and 0.350 respectively.

Test of stability of the money demand function

Figure 1 and Figure 2 are the report of the stability test from the cumulative sum (CUSUM test) and cumulative summed squared (CUSUMsq) of the recursive residuals of the money demand function in Ghana respectively.

Following Pesaran (1997) we investigate the long-run stability together with the short run dynamics of the model by applying the CUSUM test and CUSUM squared test. The results from the CUSUM test (Figure 1), shows that at 5\% significance level, the money demand function is stable since the stability curve stayed between the upper and lower bounds even though it exhibits significant drifts from the mean (zero line). However; the CUSUM squared test curve (Figure 2), lies 


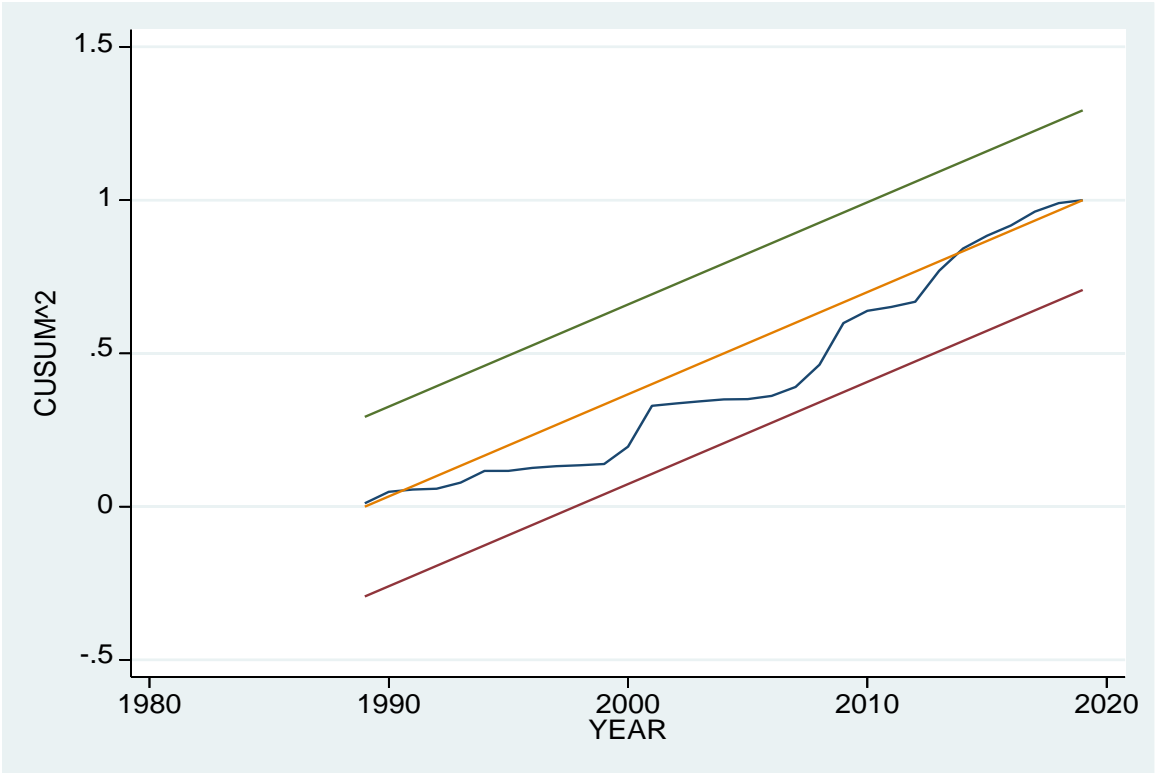

Figure 2. Cusum squared test for stability of the money demand function.

perfectly between and along the lower and upper bounds at $5 \%$ significance level and stable around the mean. This means that with the data size and the money demand determinants under consideration, the long-run money demand function is totally stable. This conclusion (total stability) based results from the CUSUM test and CUSUM squared test is consistent with the results from the stability from the vector error correction model (VECM).

\section{Discussion and Conclusion}

In this study we explored the stability of the long-run and short-run money demand functions of Ghana from 1982 to 2019 using co-integration, autoregressive distributed lag (ARDL) bounds test and a vector error correction model (VECM). The results from both the ARDL bounds test and VECM confirm the presence of long-run and short-run relationship between money demand and its determinants (real income, inflation, exchange rate, foreign interest rate and domestic interest rate). For the test and evidence of stability of the demand functions confirmed by both the CUSUM test and CUSUM squared test for stability. However; the CUSUM test curve exhibited significant drift from the mean line (zero line-curve) after the year 2012. This may partly be due to widespread failure of microfinance companies, Ponzi schemes after 2014 and the panic withdrawals that characterized the financial sector during the 2018 financial sector crisis and restructuring.

A stable monetary and financial system is a recipe for a stable macroeconomic environment and the bedrock for proper financial planning. With a stable money demand function in any economy; prices are stable and output responds predictably well without significant volatility. However; the rate of inflation, exchange rate and output growth has seen much volatility over the years which are 
partly due to the instability and temporary shocks in the monetary and financial system of Ghana. This finding of total stability of the money demand function confirms the findings of Dagher \& Kovanen (2011) who also found evidence of a stable money demand function in Ghana. This confirmation may be partly be due to the long and stable political and macroeconomic environment in Ghana even though the country has experienced some shocking waves in the monetary and financial system due to the proliferation of Ponzi schemes and bank runs in recent times.

The findings of this study are consistent with economic theory; that predicts the relationship between money demand function and its determinants. Therefore, to ensure a stable money demand function to achieve stable price, sustained economic growth, stable exchange rate environment and stable short and long-run interest rate; the Central bank of Ghana must actively keep the growth in monetary aggregates (especially M2) under control.

\section{Suggestion for Further Study}

It is suggested for further study; for the inclusion of stock market indices in the determinants of the money demand function to access how the growth and development of the Ghana Stock market is influencing monetary aggregates in Ghana.

\section{Conflicts of Interest}

The authors declare no conflicts of interest regarding the publication of this paper.

\section{References}

Ali, T., \& Abdul-Manap, T. A. (2009). Stability of Long-Run Money Demand Function: Evidence from Malaysia. IIUM Journal of Economics and Management, 17, 261-285.

Alvarez, F., \& Lippi, F. (2014). Persistent Liquidity Effects and Long-Run Money Demand. American Economic Journal: Macroeconomics, 6, 71-107. https://doi.org/10.1257/mac.6.2.71

Bahmani-oskooee, M., Chi, R., \& Ng, W. (2002). Long-Run Demand for Money in Hong Kong: An Application of the ARDL Model. International Journal of Business and Economics, 1, 147-155.

Benati, L., Lucas Jr., R. E., Nicolini, J. P., \& Weber, W. (2020). International Evidence on Long-Run Money Demand. Journal of Monetary Economics, In Press. https://doi.org/10.1016/j.jmoneco.2020.07.003

Chen, B. (1997). Long-Run Money Demand and Inflation in China. Journal of Macroeconomics, 19, 609-617. https://doi.org/10.1016/S0164-0704(97)00032-3

Dagher, J. C., \& Kovanen, A. (2011). On the Stability of Money Demand in Ghana: A Bounds Testing Approach. SSRN. https://papers.ssrn.com/sol3/papers.cfm?abstract id=1974841

Darrat, A. F., \& Al-Sowaidi, S. S. (2009). Financial Progress and the Stability of Long-Run Money Demand: Implications for the Conduct of Monetary Policy in Emerging Economies. Review of Financial Economics, 18, No. 3. 
https://onlinelibrary.wiley.com/doi/abs/10.1016/j.rfe.2009.04.003 https://doi.org/10.1016/j.rfe.2009.04.003

Dritsaki, C., \& Dritsaki, M. (2020). The Long-Run Money Demand Function: Empirical Evidence from Italy. International Journal of Economics and Financial Issues, 10, 186-195. https://ideas.repec.org/a/eco/journ1/2020-01-23.html https://doi.org/10.32479/ijefi.8943

Foresti, P., \& Napolitano, O. (2013). Modelling Long-Run Money Demand: A Panel Data Analysis on Nine Developed Economies. Applied Financial Economics, 23, 1707-1719. https://doi.org/10.1080/09603107.2013.848024

Friedman, M. (1956). The Quantity Theory of Money: A Restatement. In M. Friedman (Ed.), The Quantity Theory of Money: A Restatement in Studies in the Quantity Theory of Money (pp. 3-21). Chicago, IL: University of Chicago Press.

Haug, A. A., \& Lucas, R. F. (1996). Long-Run Money Demand in Canada: In Search of Stability. The Review of Economics and Statistics, 78, 345-348. https://doi.org/10.2307/2109938

Hoffman, D. L., Rasche, R. H., \& Tieslau, M. A. (1995). The Stability of Long-Run Money Demand in Five Industrial Countries. Journal of Monetary Economics, 35, 317-339. https://doi.org/10.1016/0304-3932(95)01189-U

Karfakis, C., \& Opoulos, M. S. (2000). On the Stability of the Long-Run Money Demand in Greece. Applied Economics Letters, 7, 83-86. https://doi.org/10.1080/135048500351861

Keynes, J. M. (1936). The General Theory of Employment, Interest and Money. First Published Macmillan Cambridge University Press, for Royal Economic Society.

Mark, N. C., \& Sul, D. (2003). Cointegration Vector Estimation by Panel DOLS and Long-Run Money Demand. Oxford Bulletin of Economics and Statistics, 65, 655-680. https://doi.org/10.1111/j.1468-0084.2003.00066.x

Nair, M., Samudram, M., \& Vaithilingam, S. (2008). Malaysian Money Demand Function Revisited: The ARDL Approach. Journal of Asia-Pacific Business, 9, 193-209. https://www.tandfonline.com/doi/abs/10.1080/10599230801981944 https://doi.org/10.1080/10599230801981944

Pedroni, P. (2001). Fully Modified OLS for Heterogeneous Cointegrated Panels. In B. H. Baltagi, T. B. Fomby, \& R. Carter Hill (Eds.), Nonstationary Panels, Panel Cointegration, and Dynamic Panels (Vol. 15, pp. 93-130). Bingley: Emerald Group Publishing Limited. https://doi.org/10.1016/S0731-9053(00)15004-2

Pesaran, M. H. (1997). The Role of Economic Theory in Modelling the Long Run. The Economic Journal, 107, 178-191. https://www.jstor.org/stable/2235280 https://doi.org/10.1111/1468-0297.00151

Pesaran, M. H., Shin, Y., \& Smith, R. J. (2001). Bounds Testing Approaches to the Analysis of Level Relationships. Journal of Applied Econometrics, 16, 289-326. https://doi.org/10.1002/jae.616

Sarwar, H., Sarwar, M., \& Waqas, M. (2013). Stability of Money Demand Function in Pakistan. Economic and Business Review, 15, 197-212.

Suliman, S. Z., \& Dafaalla, H. A. (2011). An Econometric Analysis of Money Demand Function in Sudan, 1960 to 2010. Journal of Economics and International Finance, 3, 793-800. https://doi.org/10.5897/JEIF11.122 